\title{
Os ensinamentos herdados de um grande mestre!
}

Prof. Dr. Wagner Seixas da Silva Instituto de Bioquímica Médica - Universidade Federal do Rio de Janeiro (UFRJ)

Ensinar Bioquímica é um desafio enorme no ciclo básico de muitos cursos de graduação. Como convencer o aluno de que a disciplina é importante para seu curso de graduação em um momento tão inicial da sua caminhada acadêmica? Talvez seja difícil definir em palavras uma boa estratégica didática para isso, mas, entre as décadas de $70 \mathrm{e}$ 80 , alguns professores toparam este desafio! O professor Leopoldo de Meis foi um dos que dedicaram especial atenção à forma de ensinar bioquímica. Com sua sensibilidade ele foi capaz de perceber que o segredo seria manter a motivação, acrescida de um pouco de provocação aos jovens.

Foi pensando assim que o Prof. de Meis, junto com um grupo pequeno de docentes e alunos de pós-graduação do antigo Departamento de Bioquímica Médica, hoje Instituto de Bioquímica Médica Leopoldo de Meis, da Universidade Federal do Rio de Janeiro, propôs introduzir o método da redescoberta em sala de aula. A ideia era apresentar o conteúdo da disciplina de bioquímica instigando os alunos a interpretarem os dados originais das grandes descobertas desta área. Para isso, cada tema de Bioquímica era apresentado através dos experimentos que levaram às conclusões que eram exibidas no livro didático. Desta forma, os alunos eram motivados a refazer perguntas e a propor experimentos que permitiam a interpretação dos resultados históricos dos cientistas. A metodologia parecia muito nova e difícil em um primeiro momento, mas, com o passar dos primeiros minutos de aula, o ambiente se tornava um local de ampla discussão científica, onde os alunos participavam ativamente e desenvolviam a habilidade de elaborar as questões necessárias para decifrar o funcionamento de vias metabólicas. O paralelo entre os fatos experimentais observados e o estado fisiológico do modelo experimental utilizado nos experimentos clássicos permitiam o desenvolvimento de um conhecimento amplo e crítico no aprendizado da Bioquímica.

Imaginar que já no primeiro semestre do curso de graduação o aluno era motivado a desenvolver a autonomia do pensamento crítico era algo revolucionário e bem atraente. Assim, não raro, era possível encontrar em sala de aula alunos já aprovados na disciplina, 
e cursando períodos mais adiantados no curso, voltando para participar das aulas e rever o querido professor! Nas aulas era possível discutir Bioquímica e também aprender história! Discutir os experimentos de Antoine-Laurent Lavoisier e ter a sala de aula invadida por "atores" interpretando o julgamento e decapitação de Lavoisier, mais de 100 anos após a sua morte, causava nos alunos um turbilhão de emoções. Isto os sensibilizava para o grande desafio vivido por nomes renomados da ciência que pagavam com a própria vida a defesa de suas ideias. Desta forma, os alunos se tornavam protagonistas da história e as aulas de bioquímicas se tornavam interessantes e desafiadoras. Desafio que era partilhado pelos "atores", que na verdade eram alunos do curso de pós-graduação em Química Biológica, os quais dividiam a sala de aula com o grande mestre e, desta forma, também eram tocados com a importância de se dedicar ao ensino de Ciências.

Outro ponto que criava a aproximação com os alunos da graduação era o relato do Prof. de Meis de que ninguém é dono da verdade ou de todo o conhecimento. No mundo moderno é impossível se manter atualizado o tempo todo e, por isso, acabamos nos especializando. de Meis causava certa perplexidade quando apresentava uma foto na qual mostrava todos os exemplares de uma única revista científica conceituada na área de Bioquímica publicados ao longo de um ano. Esta pilha de revistas alcançava 1,5 metros de altura! Como imaginar que todo o recente conhecimento desta área está no conteúdo de um livro de Bioquímica ocupando um número bem menor de páginas? Assim, de Meis revelava que não sabemos tudo e que precisamos saber interpretar os novos fatos, um novo experimento, um novo conceito, uma nova técnica, uma nova descoberta. Precisamos pensar e desenvolver o pensamento crítico para encaramos os desafios do mundo moderno.

Nos últimos 20 anos, o Prof. de Meis dedicou parte do seu tempo a, juntamente com um grupo de artistas da Escola de Belas Artes da UFRJ, elaborar vídeos e livros em quadrinhos que despertassem a emoção nos estudantes durante o ensino de bioquímica. Não raro era possível ouvi-lo falar da importância de despertar a emoção nos estudantes!

Nosso querido mestre nos deixou no final de 2014, mas deixou vivo em nós a necessidade de desempenharmos nossas atividades com amor, dedicação e humildade. Só assim seremos capazes de manter os jovens motivados para aprenderem Bioquímica e para encarar os desafios do mundo! 